\title{
Modulation of Sodium Transport in Alveolar Epithelial Cells by Estradiol and Progesterone
}

\author{
MANDY LAUBE, EVA KÜPPERS, AND ULRICH H. THOME \\ Department of Neonatology [M.L., U.H.T.], University of Leipzig, Leipzig 04103, Germany; Department of Molecular and Cellular \\ Anatomy [E.K.], University of Tübingen, Tübingen 72074, Germany
}

\begin{abstract}
The effects of estradiol (E2) and progesterone (P) on alveolar epithelial $\mathrm{Na}^{+}$transport were studied in isolated alveolar epithelial cells from 18- to 19-d GA rat fetuses, grown to confluence in serum-free media supplemented with E2 $(0-1 \mu \mathrm{M})$ and $\mathrm{P}(0-2.8$ $\mu \mathrm{M})$. Short-circuit currents $\left(I_{\mathrm{SC}}\right)$ were measured, showing an increase by $\mathrm{E} 2$ and $\mathrm{P}$ in a dose-dependent manner. The Na,K-ATPase subunits $-\alpha_{1}$ and $-\beta_{1}$ were detected by Western blotting, but total expression was not significantly altered. Furthermore, all three epithelial $\mathrm{Na}^{+}$channel $(\mathrm{ENaC})$ subunits $-\alpha,-\beta$, and $-\gamma$ were detected, with trends toward a higher expression in the presence of E2 and P. Real-time PCR revealed an increase of $\alpha$ - and $\beta$-ENaC expression but no alteration of $\gamma$-ENaC. In addition, the mRNA expression of cystic fibrosis transmembrane conductance regulator (CFTR) and Na,K-ATPase- $\beta_{1}$ subunit were elevated in the presence of E2 and P. Single-channel patch clamp analysis demonstrated putative highly selective and nonselective cation channels in the analyzed cells, with a higher percentage of responsive patches under the influence of E2 and $\mathrm{P}$. We conclude that $\mathrm{E} 2$ and $\mathrm{P}$ increased $\mathrm{Na}^{+}$transport in alveolar epithelial cells by enhancing the expression and activity of $\mathrm{ENaC}$ and Na,K-ATPase. (Pediatr Res 69: 200-205, 2011)
\end{abstract}

A lveolar cells constantly transport $\mathrm{Na}^{+}$ions from the apical to the basolateral side. $\mathrm{Na}^{+}$enters the cells through epithelial $\mathrm{Na}^{+}$channels $(\mathrm{ENaC})$ in the apical membrane and is extruded by $\mathrm{Na}, \mathrm{K}$-ATPases in the basolateral membrane, creating an osmotic gradient for the movement of fluid out of the alveolar space (1). This active vectorial $\mathrm{Na}^{+}$ transport is mainly responsible for alveolar fluid clearance (AFC) and is crucial for postnatal survival, as shown by mice lacking the pore-forming $\alpha$-subunit of $\mathrm{ENaC}$ (2). Furthermore, survival of adults with acute RDS (ARDS) is related to the efficiency of their AFC (3). Preterm infants with RDS had reduced airway epithelial $\mathrm{Na}^{+}$transport (4) and reduced $\mathrm{ENaC}$ expression (5) compared with preterm infants without RDS or term infants, and decreased AFC has been found to contribute to the pathogenesis of RDS (6). Therefore, mechanisms or treatments to up-regulate lung epithelial vectorial $\mathrm{Na}^{+}$transport and AFC may improve survival and decrease morbidity of preterm infants and adults with respiratory distress.

Glucocorticoids have been shown to influence vectorial $\mathrm{Na}^{+}$transport $(7,8)$. Furthermore, they profoundly modified the biophysical properties of single $\mathrm{ENaC}$ (9). Female sex

Received June 25, 2010; accepted October 6, 2010.

Correspondence: Ulrich H. Thome, M.D., Abteilung für Neonatologie, Zentrum für Frauen und Kindermedizin, Liebigstraße 20a, 04103 Leipzig, Germany; e-mail: ulrich.thome@medizin.uni-leipzig.de

Supported by DFG Grants 626/2-1 and 2-2 [U.H.T.]. steroids may also be involved in the regulation of AFC, because women with ARDS have higher AFC and higher survival than males (3), and female preterm infants have a higher survival rate and less pulmonary disease than males $(10,11)$. Moreover, preterm infants suffering from RDS showed a reduced estrogen and progesterone $(\mathrm{P})$ plasma concentration $(12,13)$. In cystic fibrosis, a disease characterized not only by defective $\mathrm{Cl}^{-}$secretion but also by $\mathrm{Na}^{+}$hyperabsorption (14), males have a better prognosis (15), possibly because stimulating effects of female sex hormones on $\mathrm{Na}^{+}$ absorption lead to increased mucus thickness. Finally, preterm infants receiving estrogen substitution in a randomized trial had significantly less respiratory distress and higher survival (16).

A few laboratory experiments also indicate that female sex steroids may increase vectorial $\mathrm{Na}^{+}$transport. Pharmacological deprivation of estrogen and $\mathrm{P}$ during pregnancy decreased AFC in newborn piglets (17). Furthermore, simultaneous administration of estradiol (E2) and P stimulated the expression of $\mathrm{ENaC}$ subunit mRNA in rat lungs and increased shortcircuit current $\left(I_{\mathrm{SC}}\right)$ in isolated rat alveolar type II cells (18). However, no measurements of Na,K-ATPase function or expression of its subunits were performed.

These findings led us to investigate the influence of female sex steroids on vectorial $\mathrm{Na}^{+}$transport, in addition to $\mathrm{ENaC}$, Na,K-ATPase, cystic fibrosis transmembrane conductance regulator (CFTR), and VEGF expression (19) in rat fetal distal lung epithelial (FDLE) cells.

\section{METHODS}

FDLE cell isolation and culture. FDLE cells were isolated as described previously $(8,20,21)$. For Ussing chamber experiments, cells were seeded on Costar Snapwell No. 3407 (Corning, Inc., Corning, NY) at a density of $10^{6}$ cells per insert. For single-channel recordings, the cells were plated on inserts No. P2322 (Physiologic Instruments, Inc., CA) by using the Collagen Matrix Casting Protocol supplied by the manufacturer. For protein and mRNA expression analysis, cells were seeded on Transwell No. 3412 (Corning) at a density of $2 \times 10^{6}$ cells per insert. The medium was changed daily, serum-

Abbreviations: AFC, alveolar fluid clearance; ARDS, acute RDS; amil $_{\text {max }}$, amiloride-sensitive component of the amphotericin B-induced $I_{\mathrm{SC}}$; CFTR, cystic fibrosis transmembrane conductance regulator; $\mathbf{E N a C}$, epithelial $\mathrm{Na}^{+}$ channel; ER, estrogen receptor; E2, estradiol; FDLE, fetal distal lung epithelia; HSC, highly selective cation channel; $\boldsymbol{I}_{\text {amil }}$, amiloride-sensitive current; $\boldsymbol{I}_{\text {ouab }}$, ouabain-sensitive current; $\boldsymbol{I}_{\mathbf{S C}}$, short-circuit current; KNRK, Kristen sarcoma virus transformed normal rat kidney; $\mathbf{N S C}$, nonselective cation channel; ouab $_{\text {max }}$, ouabain-sensitive component of the amphotericin B-induced $I_{\mathrm{SC}} ; \mathbf{P}$, progesterone; $\boldsymbol{R}_{\text {te }}$, transepithelial resistance 
free complete medium (Cellgro; Mediatech, Herndon, VA), supplemented with E2 and P (Sigma Chemical Co., Germany) as shown in Table 1, was used from the second day onward. Cells subjected to the different experimental conditions were always age matched and derived from the same litter.

Measurement of bioelectric properties of FDLE monolayers. Experiments were performed on the fourth or fifth day of culture, which was $\sim 72-96 \mathrm{~h}$ after seeding and $48-72 \mathrm{~h}$ after applying E2 and P. The procedures of measurement are reported elsewhere $(8,20,21)$. Ussing chamber experiments were included in the analysis only when the transepithelial resistance $\left(R_{\mathrm{te}}\right)$ exceeded $300 \Omega \cdot \mathrm{cm}^{2}$. Significant differences among group means and interactions were determined by three-way ANOVA and Dunnett's post hoc test, using SAS software (SAS Institute, Cary, NC).

Single-channel recordings. The cells were seeded on slides with low density and cultured as described earlier. After mounting onto the stage of an inverted microscope, they were perfused with a solution containing the following: $\mathrm{Na}^{+}, 135 \mathrm{mM} ; \mathrm{K}^{+}, 5 \mathrm{mM} ; \mathrm{Ca}^{2+}, 1 \mathrm{mM} ; \mathrm{Mg}^{2+}, 4 \mathrm{mM} ; \mathrm{Cl}^{-}, 10 \mathrm{mM}$; gluconate, $135 \mathrm{mM}$; HEPES, $10 \mathrm{mM}$; glucose, $5 \mathrm{mM}$, and mannitol, $10 \mathrm{mM}$ (ph 7.4). Patch pipettes were pulled from quartz capillaries with $1 \mathrm{~mm}$ outer diameter and 0.7 $\mathrm{mm}$ inner diameter (Sutter, Novato, CA) with a P2000 laser puller (Sutter) and filled with a solution containing the following: $\mathrm{Na}^{+}, 135 \mathrm{mM} ; \mathrm{Mg}^{2+}, 5 \mathrm{mM} ; \mathrm{Cl}^{-}$, $10 \mathrm{mM}$; gluconate, $135 \mathrm{mM}$; HEPES, $10 \mathrm{mM}$; and glucose, $5 \mathrm{mM}$ (ph 7.4), resulting in a tip resistance between 5 and $10 \mathrm{M} \Omega$. After forming a gigaseal, cells were depolarized by switching the bath perfusion to a solution containing the following $\mathrm{K}^{+}, 135 \mathrm{mM} ; \mathrm{Mg}^{2+}, 5 \mathrm{mM} ; \mathrm{Cl}^{-}, 10 \mathrm{mM}$; gluconate, $135 \mathrm{mM}$; HEPES, $10 \mathrm{mM}$; glucose, $5 \mathrm{mM}$; and mannitol, $20 \mathrm{mM}$ (ph 7.4). Single-channel currents were recorded in cell attached mode at a membrane potential of -100 $\mathrm{mV}$ and room temperature, filtered at $2 \mathrm{kHz}$ and sampled at $5 \mathrm{kHz}$, using an EPC 9 amplifier (HEKA, Göttingen, Germany). Recordings were analyzed with QUB software (Research Foundation, State University, Buffalo, NY). Traces were digitally filtered at $400 \mathrm{~Hz}$ and idealized using the Segmental-K-Means algorithm (22). From amplitude histograms, single-channel conductance, open probability, and dwell time were calculated. The number of responsive patches with active channels in each medium was determined, and results were analyzed with Fisher's exact test using SigmaStat software (Systat Software GmbH, Erkrath, Germany).

Measurement of $m R N A$ expression. Total RNA was isolated on the fifth day of culture using the RNeasy Kit (Qiagen, Germany). Reverse transcription was carried out in two steps with first preannealing of $10 \mu \mathrm{L}$ RNA followed by $1 \mathrm{~h}$ at $55^{\circ} \mathrm{C}$ and $15 \mathrm{~min}$ at $75^{\circ} \mathrm{C}$ using Oligo(dT) $)_{18}$ primers and SuperscriptIII. The qPCR was carried out using the Platinum Taq-polymerase and gene-specific primers (Table 2). Reactions were conducted with the IQ5 RT-PCR Detection System (BioRad, Germany) with SYBR-Green (Molecular Probes, Eugene, OR) under the following conditions: 3-min enzyme activation at $95^{\circ} \mathrm{C}, 30$ cycles of $30 \mathrm{~s}$ denaturation at $95^{\circ} \mathrm{C}, 30 \mathrm{~s}$ annealing at individual temperatures, and $30 \mathrm{~s}$ amplification at $72^{\circ} \mathrm{C}$. Dilutions of plasmid DNA were used as internal standard. The resulting concentrations were normalized to a reference gene hydroxymethylbilane synthase (HMBS). Constant expression of the reference gene was tested against other housekeeping genes (not shown). Melting curves and gel electrophoresis of the PCR products were routinely performed to assure the specificity of the PCR reaction.

Table 1. Media composition

\begin{tabular}{ll}
\hline Medium 1 & Without E2 and P \\
Medium 2 & $0.01 \mu \mathrm{M} \mathrm{E2}$ \\
Medium 3 & $0.01 \mu \mathrm{M} \mathrm{E2}$ and $0.1 \mu \mathrm{M} \mathrm{P}$ \\
Medium 4 & $0.28 \mu \mathrm{M} \mathrm{E2}$ and $0.037 \mu \mathrm{M} \mathrm{P}$ \\
Medium 5 & $0.0037 \mu \mathrm{M}$ E2 and $2.8 \mu \mathrm{M} \mathrm{P}$ \\
Medium 6 & $1 \mu \mathrm{M} \mathrm{E2} \mathrm{and} 1 \mu \mathrm{M} \mathrm{P}$ \\
\hline
\end{tabular}

Measurement of transport protein expression. Western blot studies of $\mathrm{ENaC}$ and $\mathrm{Na}, \mathrm{K}-\mathrm{ATPase}$ subunits were performed as described $(8,20,21)$. Proteins were detected with rabbit antibodies against $\alpha$-ENaC (Alpha Diagnostics, San Antonio, TX), $\beta$-ENaC (H-190; Santa Cruz Biotechnology, Santa Cruz, CA), $\gamma$-ENaC (Alpha Diagnostics), and $\alpha_{1}-\mathrm{Na}$, K-ATPase or $\beta_{1}-\mathrm{Na}$, K-ATPase (both Upstate Biotechnology, Waltham, MA), diluted 1:1,000. Secondary antibodies coupled to horseradish peroxidase (HRP) were diluted 1:10,000 and HRP activity detected by enhanced chemiluminescence (ECL; Amersham, Piscataway, NJ) on X-ray film. Band intensity was measured by densitometry using an Image Master VDS scanner (Pharmacia, Piscataway, $\mathrm{NJ})$ and compared between groups by the Mann Whitney $U$ test.

\section{RESULTS}

Electrophysiologic studies of complete monolayers. All FDLE cells used in the electrophysiological studies were obtained from 15 different cell isolations. Of 545 monolayers, $333 \mathrm{had}$ an $R_{\mathrm{te}}>300 \Omega \cdot \mathrm{cm}^{2}$ and were included in the analysis, and their mean $R_{\mathrm{te}}$ was $644 \pm 281 \Omega \cdot \mathrm{cm}^{2}$ $($ mean $\pm \mathrm{SD})$.

Baseline $I_{\mathrm{SC}}\left(\mu \mathrm{A} / \mathrm{cm}^{2}\right)$ was significantly increased when E2 or E2/P had been present in the cell culture medium (ANOVA, $p<0.01$, Fig. 1). The strongest increase from $10.05 \pm 0.25$ to $12.09 \pm 0.69$ was found in monolayers grown in medium 4, containing $0.28 \mu \mathrm{M}$ E2 and $0.037 \mu \mathrm{M} \mathrm{P}$, which was significant by Dunnett's post hoc test $(p<0.05)$. Similarly, amiloride-sensitive current $\left(I_{\text {amil }}\right)$ was significantly increased by E2 or E2/P in the cell culture medium $(p<0.0001)$ and maximal in monolayers grown in medium 4 , which showed an elevation from $7.80 \pm 0.20$ to $9.87 \pm 0.50$. Ouabain-sensitive current $\left(I_{\text {ouab }}\right)$ was also significantly increased by adding E2 or E2/P to the cell culture medium $(p<0.001)$. In addition, the maximal response from $8.18 \pm 0.22$ to $10.24 \pm 0.51$ was found in monolayers grown in medium 4. Maximal current differences between monolayers grown in medium 1 and 4 were $\sim 20 \%$.

In monolayers used for experiments with permeabilized apical membrane in symmetrical ion compositions (Fig. 2A), baseline current was significantly increased overall $(p<$ $0.0001)$ and specifically in monolayers grown in media 2 and 4 by Dunnett's post hoc test $(p<0.05)$. After permeabilizing the apical membrane with amphotericin $\mathrm{B}$, thus loading the cell interior and the $\mathrm{Na}, \mathrm{K}-\mathrm{ATPases}$ with $\mathrm{Na}^{+}, I_{\mathrm{SC}}$ increased by $\sim 50 \%$, and most strongly in monolayers grown in medium 4 (Fig. 2A). The ouabain-sensitive component of the amphotericin B-induced $I_{\mathrm{SC}}\left(\right.$ ouab $_{\max }$ ) was significantly increased by $\mathrm{E} 2$ or E2/P in the cell culture medium (ANOVA, $p<0.001$ ), with a maximum response observed after growth in medium 4 , increasing ouab ${ }_{\max }$ by $\sim 35 \%$ from $12.51 \pm 0.72$ to $17.06 \pm$

Table 2. Primer sequences

\begin{tabular}{lll}
\hline \multicolumn{1}{c}{ Gene } & \multicolumn{1}{c}{ Primer (forward) } & \multicolumn{1}{c}{ Primer (reverse) } \\
\hline$\alpha-E N a C$ & TTCTGGGCGGTGCTGTGGCT & GCGTCTGCTCCGTGATGCGG \\
$\beta-E N a C$ & TGCAGGCCCAATGCCGAGGT & GGGCTCTGTGCCCTGGCTCT \\
$\gamma-E N a C$ & CACGCCAGCCGTGACCCTC & CTCGGGACACCACGATGCGG \\
$E a-$ - - ATPase $-\beta_{I}$ & GCGCAGCACTCGCTTTCCT & GGGCCACACGGTCCTGGTACG \\
$E R-\beta$ & CACACACCGCGCCACTCGAT & GCATCTTGAGCTGCGGGCGA \\
$C F T R$ & CTGGTGAGCCGTCCCAGCATG & GGTGGTCGATGGAGCGCCAC \\
$V E G F-A$ & GCCTTCGCTGGTTGCACAGTAGTC & GCTTCTCCAGCACCCAGCACTAGA \\
$H M B S$ & CCAGGCTGCACCCACGACAG & GCCCGCACACCGCATTAGGG \\
& CCCTGAGGAGAGTGGCGCAGC & GACCTCCACCGCCAGGGCTC \\
\hline
\end{tabular}




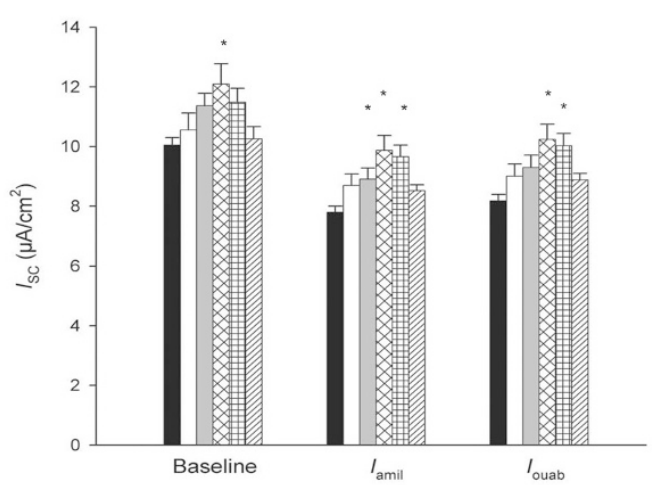

Figure 1. Effect of $\mathrm{E} 2$ and $\mathrm{P}$ exposure during cell culture on $I_{\mathrm{SC}}$ in rat FDLE cells. Baseline was the $I_{\mathrm{SC}}$ after mounting the monolayers in the Ussing chambers, $I_{\text {amil }}$ the current reduction by amiloride $(10 \mu \mathrm{M})$, and $I_{\text {ouab }}$ the ouabain- $(1 \mathrm{mM})$ sensitive current. Media 1 to 6 refer to the concentrations of $\mathrm{E} 2$ and $\mathrm{P}$ in the culture medium as outlined in Table 1. Error bars represent SEM, $* p<0.05$ by Dunnett's post hoc test. Medium $1(\square)$, medium $2(\square)$,

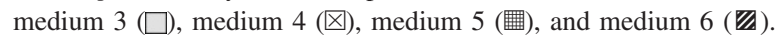

1.13. No increase of ouab $b_{\max }$ was observed in monolayers grown in medium 5 or 6 (Fig. 2A).

The amiloride-sensitive component of the amphotericin B-induced $I_{\mathrm{SC}}\left(\right.$ amil $\left._{\max }\right)$, measured in the presence of a 145:5 apical to basolateral $\mathrm{Na}^{+}$gradient and permeabilized basolateral membrane was also increased by $\mathrm{E} 2$ and $\mathrm{P}$ in the cell culture medium $(p<0.001)$. Unlike ouab ${ }_{\max }$, amil ${ }_{\max }$ was highest in monolayers grown in the P-rich medium 5, which showed an increase from $13.75 \pm 0.41$ to $18.39 \pm 1.46$. Growth in mediums
4 and 6 resulted in a smaller but still significantly increased amil $_{\max }$ ( $p<0.05$ by Dunnett's post hoc test; Fig. $2 B$ ).

Single-channel analysis. The analyzed FDLE cells showed $\mathrm{Na}^{+}$channels with a conductance close to $4 \mathrm{pS}$, typical for the highly selective cation channel (HSC), and $23 \mathrm{pS}$, typical for the nonselective cation channel (NSC). Tracings are shown in Fig. 3A. Putative HSC and NSC channels were observed in all media, and there were no differences in open probability and dwell times between media. However, the proportion of responsive patches with active channels significantly increased depending on hormone supplementation (Fisher's exact test, $p<0.05$ between medium 1 and 6; Fig. 3B).

Analysis of mRNA expression. The mRNA analysis of the examined FDLE cells revealed different expression pattern for the ion transporters. The $\alpha$ - and $\beta$-ENaC subunits were increased under $\mathrm{E} 2$ and $\mathrm{P}$ influence. The $\alpha$-ENaC subunit expression showed a $>3$-fold increase in the medium 5 compared with medium 1 (ANOVA, $p<0.01$, Fig. $4 A$ ) and a $>2$-fold elevation in medium 6 (ANOVA, $p<0.01$ ). Both increases were also significant by Dunnett's post hoc test ( $p<$ 0.05). The mRNA expression of the $\beta$-ENaC subunit was elevated up to $190 \%$ in medium 4 and 6 compared with medium 1 (ANOVA, $p<0.01, p<0.05$ by Dunnett's post hoc test; Fig. $4 B$ ). No profound changes in the expression of $\gamma$-ENaC were observed (Fig. $4 C$ ).

The Na,K-ATPase- $\beta_{1}$ mRNA expression was also increased in the media containing E2 and $\mathrm{P}$, with no pronounced difference between the different E2 and P concentrations $(p<$ 0.05 by Dunnett's post hoc test, Fig. $5 A$ ). The elevation of the
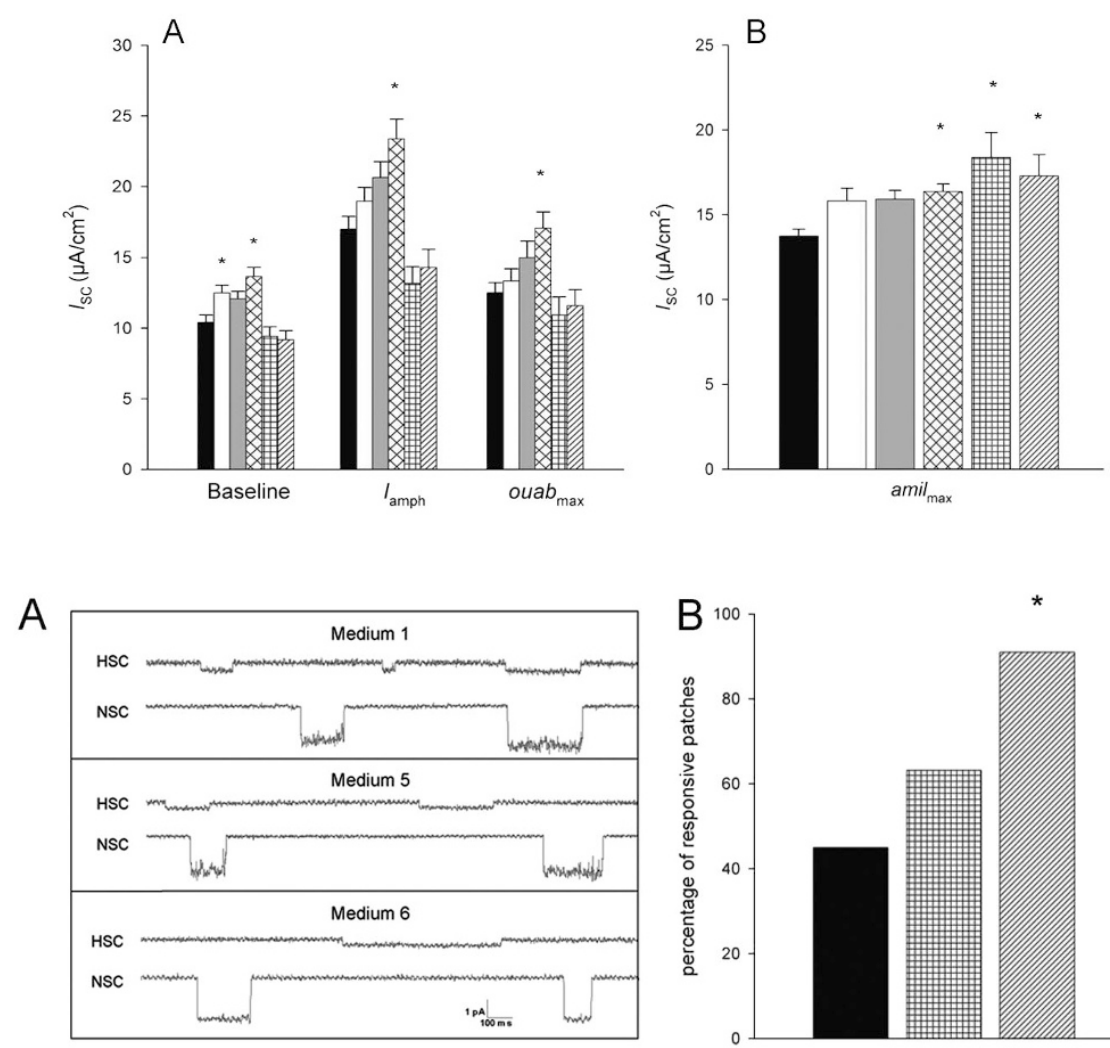

Figure 2. (A) Effect of E2 and P exposure during cell culture on ouab ${ }_{\max }$ in rat FDLE cells. Baseline was the $I_{\mathrm{SC}}$ after mounting the monolayers in the Ussing chambers, $I_{\text {amph }}$ the current after adding 10 $\mu \mathrm{M}$ amphotericin $\mathrm{B}$ to the apical compartment, and ouab ${ }_{\max }$ the current reduction caused by $1 \mathrm{mM}$ ouabain. (B) Effect of E2 and P exposure during cell culture on amil $\mathrm{m}_{\max }$ in rat FDLE cells. The monolayers were subjected to a $145: 5$ apical to basolateral $\mathrm{Na}^{+}$gradient, the basolateral membrane permeabilized by $100 \mu \mathrm{M}$ amphotericin $\mathrm{B}$, and $10 \mu \mathrm{M}$ amiloride was given into the apical compartment at the maximum current increase. ${ }^{*} p<0.05$ by Dunnett's post hoc test. Medium 1 $(\square)$, medium 2 ( $\square$ ), medium $3(\square)$, medium 4 ( $\otimes)$,

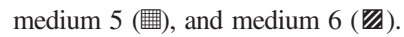

Figure 3. (A) Single-channel recordings of rat FDLE cells subjected to different concentrations of E2 and P. HSC represents a putative highlyselective cation channel of $\mathrm{ENaC}$ with a unitary conductance of $\sim 4 \mathrm{pS}$. NSC refers to a putative nonselective cation channel of $\mathrm{ENaC}$ with a unitary conductance of $\sim 23 \mathrm{pS}$. (B) Comparison of the percentage of responsive patches showing single-channel activity in cells incubated with different concentrations of E2 and P $(n=20$ for medium $1, n=19$ for medium 5 , and $n=11$ for medium 6$) . *_{p}<0.05$ by Fisher's exact test.

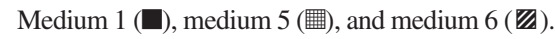



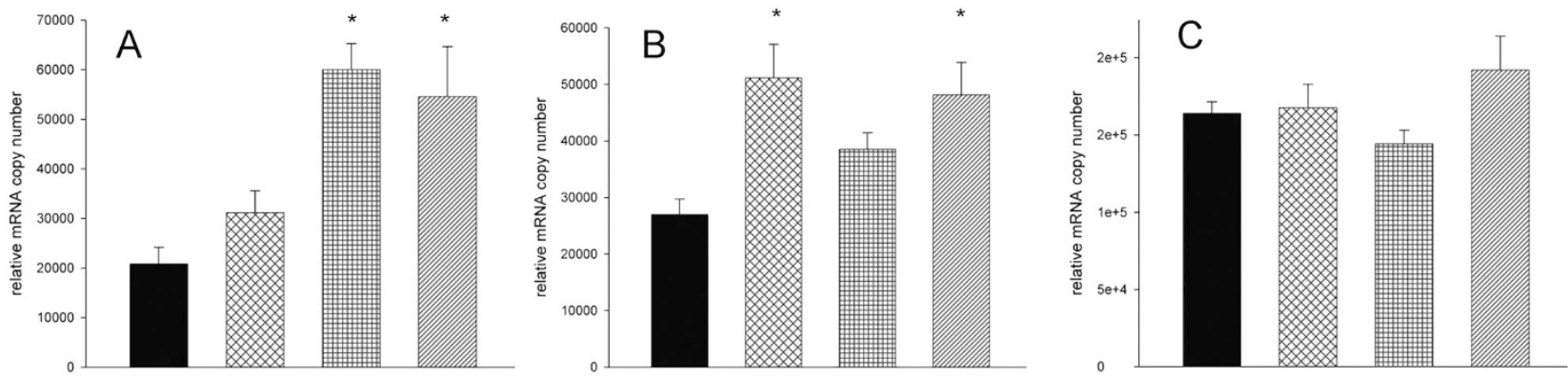

Figure 4. The RT-PCR analysis of the mRNA expression level of the $\alpha$-ENaC subunit $(A)$, the $\beta$-ENaC subunit $(B)$, and the $\gamma$-ENaC subunit $(C)$ in rat FDLE

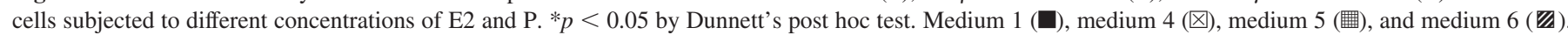

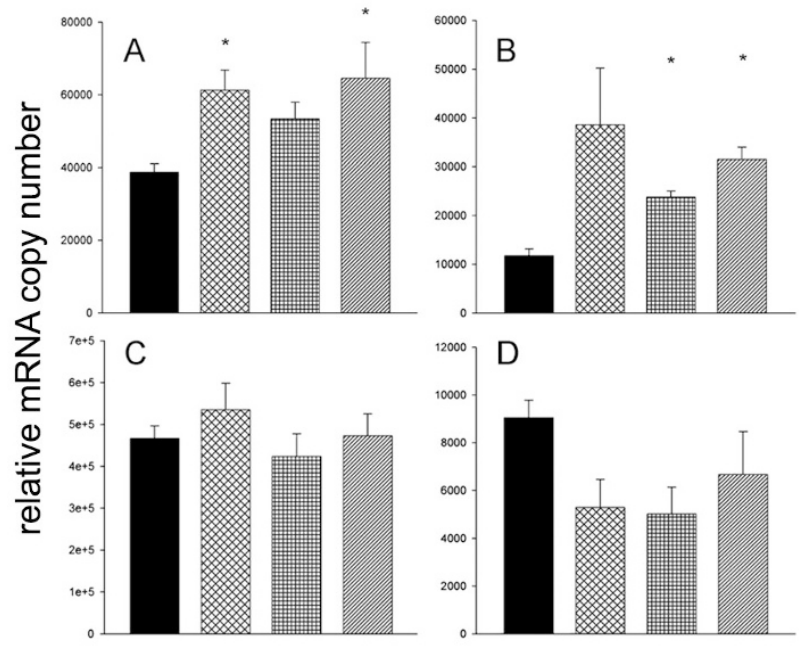

Figure 5. The RT-PCR analysis of the mRNA expression level of the Na,K-ATPase- $\beta_{1}$ subunit $(A)$, CFTR $(B)$, VEGF-A $(C)$, and ER- $\beta(D)$ in rat FDLE cells subjected to different concentrations of $\mathrm{E} 2$ and $\mathrm{P} .{ }^{*} p<0.05$ by Dunnett's post hoc test. Medium $1(\square)$, medium 4 (区), medium 5 (羁), and medium $6(\mathbb{Z})$.

$\mathrm{Na}, \mathrm{K}-\mathrm{ATPase}-\beta_{1}$ mRNA expression was in the range of $40-$ $60 \%$ for all E2- and P-supplemented media. A significant elevation of the CFTR-mRNA was detected in media 5 and 6 $(p<0.05$ by Dunnett's post hoc test, Fig. $5 B)$ and a trend toward an increase in medium 4 . The putative mediator of steroid action VEGF-A was not altered in the presence of E2 and $\mathrm{P}$ (Fig. 5C). The estrogen receptor (ER)- $\alpha$ was not found in the FDLE cells, but primer specificity was demonstrated using rat ovary tissue as a positive control (not shown). The ER- $\beta$ mRNA expression was detected and showed a trend toward a decreased expression under the influence of E2 and P (Fig. 5D).

Protein expression analysis. FDLE cells used for Western blotting were obtained from six different experiments. All three subunits of $\mathrm{ENaC}$ were detected in the same cell lysates in bands located at $\sim 90-110 \mathrm{kD}$ (Fig. $6 A$ ), although signals of the $\beta$ - and $\gamma$-subunits were considerably weaker than that of the $\alpha$-subunit. Specificity of the antibody binding was confirmed by competition of antibody binding using a control peptide, by detection of $\mathrm{ENaC}$ subunits with exactly the same molecular weight in a commercial rat kidney cell lysate [Kristen sarcoma virus transformed normal rat kidney

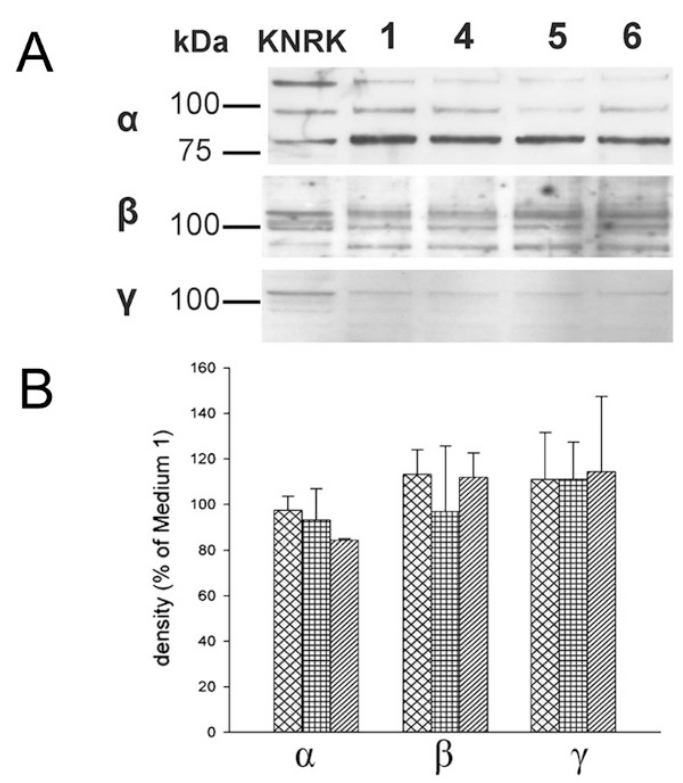

Figure 6. (A) Western blot of $\alpha-, \beta$-, and $\gamma$-ENaC subunits in FDLE cells grown in the presence of different concentrations of E2 and P. The numbers on top refer to the $\mathrm{E} 2$ and $\mathrm{P}$ concentrations in the culture medium as outlined in Table 1. KNRK refers to a commercial rat kidney cell lysate, serving as a positive control. (B) Densitometric analysis of the Western blots of $\alpha-, \beta-$, and $\gamma$-ENaC subunits. Values are shown as percentage of the density obtained from cells grown in medium 1 (all bars, $n=6$ ). Medium $4(\bigotimes)$, medium 5 (瞣), and medium 6 ( $)$.

(KNRK), Santa Cruz], and by omitting the primary antibody. Although lysates of cells grown in media 4,5 , and 6 tended to yield darker bands and higher optical densities of $\beta$ and $\gamma$ $\mathrm{ENaC}$, the differences were too small for statistical significance (Fig. 6B).

In lysates from FDLE cells as well as in the positive controls from brain tissue, the $\alpha_{1^{-}}$and $\beta_{1}$-subunits of the $\mathrm{Na}, \mathrm{K}$-ATPase yielded bands corresponding to a molecular weight of 110 and $47 \mathrm{kD}$, respectively, (Fig. 7A). Treatment with $\mathrm{E} 2$ and $\mathrm{P}$ did not result in a significantly different expression of either subunit (Fig. 7B).

\section{DISCUSSION}

To our knowledge, this is the first study investigating the effects of different $\mathrm{E} 2$ and $\mathrm{P}$ concentrations on both apical $\mathrm{Na}^{+}$ channels and Na,K-ATPase activity in FDLE cells. The in- 

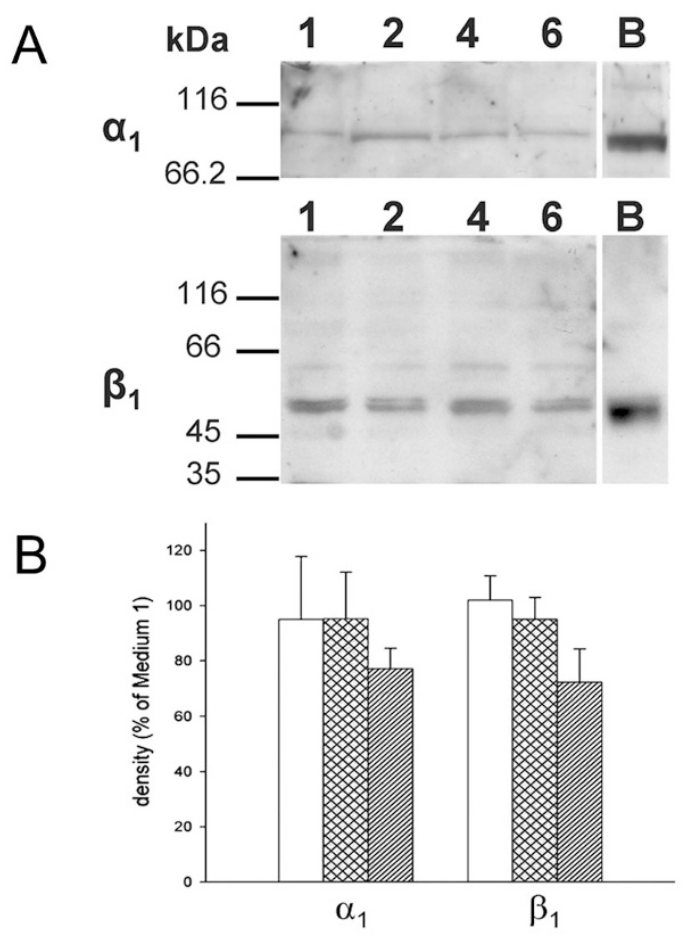

Figure 7. (A) Western blot of Na,K-ATPase- $\alpha_{1}$ and $-\beta_{1}$ subunits in FDLE cells grown in the presence of different concentrations of E2 and P. B is the positive control obtained from rat brain tissue. $(B)$ Densitometric analysis of the Western blots of Na,K-ATPase- $\alpha_{1}$ and $-\beta_{1}$ subunits. Values are shown as percentage of the density obtained from cells grown in medium 1 ( $n=6$ for $\alpha_{1}$ and $n=10$ for $\beta_{1}$ ). Medium $2(\square)$, medium $4(\bigotimes)$, and medium $6(\mathbb{Z})$.

creases of baseline $I_{\mathrm{SC}}, I_{\mathrm{amil}}, I_{\mathrm{ouab}}$, ouab ${ }_{\max }$, and amil $1_{\max }$ in monolayers exposed to E2 up to $0.28 \mu \mathrm{M}$ (medium 4) are consistent with stimulatory effects on both $\mathrm{ENaC}$ and $\mathrm{Na}$, K-ATPase. High concentrations of P (1-2.8 $\mu \mathrm{M}$, medium 6 and 5) were associated with diminished currents and also a trend toward reduced $\mathrm{Na}, \mathrm{K}-\mathrm{ATPase}$ protein expression, which may indicate toxicity. A high $\mathrm{P}$ concentration combined with a low E2 concentration, as in medium $5(2.7 \mu \mathrm{M})$, predominantly increased $\mathrm{ENaC}$ activity, as shown by stimulatory effects on amil $_{\max }$ but not ouab ${ }_{\max }$. Hence, the decreases of baseline $I_{\mathrm{SC}}$ in media 5 and 6 were probably caused by a diminished Na,K-ATPase activity. Smaller stimulatory effects on apical $\mathrm{Na}^{+}$channel activity were also seen using media 2 and 3, resembling $\mathrm{E} 2$ and $\mathrm{P}$ concentrations similar to natural conditions during rat gestation (23). It was also shown that the combination of $\mathrm{E} 2$ and $\mathrm{P}$ (e.g. medium 5 with $0.0037 \mu \mathrm{M}$ E2) has a higher impact on epithelial $\mathrm{Na}^{+}$transport than E2 alone as in medium $2(0.01 \mu \mathrm{M} \mathrm{E} 2)$. This would suggest a more pronounced influence of $\mathrm{P}$, but considering the effects of medium 3 with a higher $\mathrm{P}$, but lower E2 concentration than medium 4, a more complex interaction between intracellular E2 and P signaling must be assumed. The notion of a physiologic role of female sex steroids on lung epithelial ion transport is further supported by a study of pig fetuses subjected to prenatal pharmacologic E2 and P withdrawal, which resulted in decreased amiloride-sensitive AFC (17).

Vectorial ion transport of intact cells is always a cooperation of apical and basolateral transporters. By selective per- meabilization, we were able to separate the effects on basolateral $\mathrm{Na}, \mathrm{K}-\mathrm{ATPase}$ and apical $\mathrm{Na}^{+}$channels. $\mathrm{Na}, \mathrm{K}-\mathrm{ATPase}$ function was increased by female sex steroids, which is a novel finding in epithelial cells. Apical $\mathrm{Na}^{+}$channels have been sparsely investigated, yielding results consistent with the findings described in this work. ENaC subunit mRNA expression has been shown to be enhanced in rat kidney cells (24). Higher levels of $\alpha$-ENaC were detected in female rat lungs compared with males, and combined administration of E2 and $\mathrm{P}$ to immature or ovarectomized rats increased pulmonary mRNA levels of $\alpha$ - and $\gamma$-ENaC after $24 \mathrm{~h}$ (18). Furthermore, monolayers of alveolar epithelial cells derived from immature rats responded to $\mathrm{E} 2$ and $\mathrm{P}$ with an increase in amiloridesensitive $I_{\mathrm{SC}}$, using the same $\mathrm{E} 2$ and $\mathrm{P}$ concentrations as in our medium 5 (18). However, no investigations regarding the $\mathrm{Na}, \mathrm{K}-\mathrm{ATPase}$ were included.

A comparison of single-channel activity between cells in the control and supplemented media showed a higher percentage of active patches in cells grown in medium 6. The open probability of single channels was not increased; however, more channel units seem to be available, which is consistent with a higher membrane permeability. Thus, a higher number of active $\mathrm{ENaC}$ induced by $\mathrm{E} 2$ and $\mathrm{P}$ is in accordance with the $I_{\mathrm{SC}}$ measurements.

We demonstrated that $\alpha$ - and $\beta$-ENaC subunit mRNA expression is enhanced in the media supplemented with E2 and $\mathrm{P}$. The strongest increase of $\alpha$-ENaC mRNA was observed for the P-rich medium 5, which was also showing the highest amil $1_{\max }$. Unlike the whole animal experiments (18), we did not find an increase of $\gamma$-ENaC mRNA expression but an elevation of $\beta$-ENaC. These results also demonstrate a differential regulation of ENaC subunits by sex steroids. Furthermore, this study shows increased expression of $\mathrm{Na}, \mathrm{K}$ ATPase- $\beta_{1}$ subunit by E2 and $\mathrm{P}$ at all tested concentrations. Overexpression of the $\beta_{1}$-subunit of the Na,K-ATPase alone was previously shown to increase vectorial $\mathrm{Na}^{+}$transport, whereas overexpression of the $\alpha_{1}$-subunit did not have any effect (21), because the $\beta_{1}$-subunit was the rate-limiting component in the assembly of Na,K-ATPases $(25,26)$. Therefore, the observed increased expression of the Na,K-ATPase- $\beta_{1}$ subunit might account for the detected elevation of $I_{\text {ouab }}$ under E2 supplementation. CFTR mRNA expression was shown to be increased by combined treatment of E2 and P after $24 \mathrm{~h}$ (18), which we also demonstrated on the fourth day after hormone supplementation. These data show the impact of E2 and $\mathrm{P}$ on the transcriptional level of participating ion transporters. E2 and $\mathrm{P}$ supplementation resulted in a trend toward a reduced expression of ER- $\beta$, which has been described for the expression of ER in the brain (27); however, to our knowledge, it has not yet been described in the lung.

The increases in vectorial $\mathrm{Na}^{+}$transport of $\sim 20 \%$ are corroborated by up to $20 \%$ higher densities of $\beta$ - and $\gamma$-ENaC subunits in Western blots, although the latter effect was not statistically significant. The polyclonal origin of the antibodies resulted in detection of several bands. For evaluation by densitometry, the band with the best-fitting molecular weight was selected. Specificity was further confirmed by experiments with positive controls. Because of the high variability of 
such measurements, a large number of Western blots would be needed for statistical verification at this effect size. Expression of Na,K-ATPase remained essentially unchanged in culture media 2 and 4. The protein expression results do not completely rule out a minor increase sufficient to produce the electrophysiologically detected changes, because whole cell lysates also include proteins stored in the endoplasmatic reticulum and blotting studies cannot be readily expected to detect small differences, as previously reported (8).

Some effects of E2 and P on ion transport may have been partly mediated through other ion channels, e.g. $\mathrm{K}^{+}$channels, which are an essential part of the $\mathrm{Na}^{+}$transport machinery as they recycle $\mathrm{K}^{+}$at the basolateral membrane and also control the membrane resting potential $(28,29) . \mathrm{K}^{+}$channels in other tissues have been shown to be controlled by E2 (30,31). It is currently unknown whether $\mathrm{K}^{+}$channels in epithelial cells are influenced by E2 or P. FDLE cells are known to perform mostly not only $\mathrm{Na}$ absorption but also, to a smaller extent, $\mathrm{Cl}^{-}$secretion (8). Therefore, we used the specific inhibitors of epithelial $\mathrm{Na}^{+}$transport, amiloride and ouabain, to attribute the effects of hormone supplementation to the $\mathrm{ENaC}$ and $\mathrm{Na}, \mathrm{K}-\mathrm{ATPase}$ transport activity. Furthermore, experiments performed in $\mathrm{Cl}^{-}$-free solution yielded similar results (not shown).

In conclusion, our data indicate that $\mathrm{ENaC}$ and $\mathrm{Na}, \mathrm{K}$ ATPase function in rat FDLE cells is increased by exposure to $\mathrm{E} 2$ as well as E2 and P. ENaC activity seems to be most strongly stimulated by high $\mathrm{P}$ concentrations, whereas the $\mathrm{Na}, \mathrm{K}-\mathrm{ATPase}$ function seems to be mainly controlled by E2, which is a new finding. E2 and P may thus improve AFC and hasten the resolution of pulmonary edema, which may contribute to positive effects of E2 on RDS of infants $(10,16)$ and the sex-related differences in the survival of the ARDS (3). In cystic fibrosis, stimulatory actions of E2 and P may worsen the overactivity of ENaC associated with the disease (14), which may explain why the prognosis of affected males is better than that of females (15).

Acknowledgments. We thank Reinhard Rüdel and Paul Dietl, Department of General Physiology, and Frank Lehmann-Horn, Department of Applied Physiology, both from University of Ulm, Germany, for providing laboratory facilities, and Chrissoula Kiote, Traudl Hiller, Uwe Kirchner, Natalie Damm, Tatiana Felder, Sylvia Taube, and Maike Ziegler for excellent technical assistance.

\section{REFERENCES}

1. Matalon S, O'Brodovich H 1999 Sodium channels in alveolar epithelial cells: molecular characterization, biophysical properties, and physiological significance. Annu Rev Physiol 61:627-661

2. Hummler E, Barker P, Gatzy J, Beermann F, Verdumo C, Schmidt A, Boucher R, Rossier BC 1996 Early death due to defective neonatal lung liquid clearance in $\alpha$ ENaC-deficient mice. Nat Genet 12:325-328
3. Ware LB, Matthay MA 2001 Alveolar fluid clearance is impaired in the majority of patients with acute lung injury and the acute respiratory distress syndrome. Am J Respir Crit Care Med 163:1376-1383

4. Barker PM, Gowen CW, Lawson EE, Knowles MR 1997 Decreased sodium ion absorption across nasal epithelium of very premature infants with respiratory distress syndrome. J Pediatr 130:373-377

5. Helve O, Pitkanen OM, Andersson S, O'Brodovich H, Kirjavainen T, Otulakowski G 2004 Low expression of human epithelial sodium channel in airway epithelium of preterm infants with respiratory distress. Pediatrics 113:1267-1272

6. O'Brodovich HM 1996 Immature epithelial $\mathrm{Na}+$ channel expression is one of the pathogenetic mechanisms leading to human neonatal respiratory distress syndrome. Proc Assoc Am Physicians 108:345-355

7. Tchepichev S, Ueda J, Canessa C, Rossier BC, O’Brodovich H 1995 Lung epithelial $\mathrm{Na}$ channel subunits are differentially regulated during development and by steroids. Am J Physiol 269:C805-C812

8. Thome UH, Davis IC, Nguyen SV, Shelton BJ, Matalon S 2003 Modulation of sodium transport in fetal alveolar epithelial cells by oxygen and corticosterone. Am J Physiol Lung Cell Mol Physiol 284:L376-L385

9. Lazrak A, Samanta A, Venetsanou K, Barbry P, Matalon S 2000 Modification of biophysical properties of lung epithelial $\mathrm{Na}(+)$ channels by dexamethasone. Am J Physiol Cell Physiol 279:C762-C770

10. Naeye RL, Burt LS, Wright DL, Blanc WA, Tatter D 1971 Neonatal mortality, the male disadvantage. Pediatrics 48:902-906

11. Hallman M, Haataja R 2003 Genetic influences and neonatal lung disease. Semin Neonatol 8:19-27

12. Parker CR Jr, Hankins GD, Guzick DS, Rosenfeld CR, MacDonald PC 1987 Ontogeny of unconjugated estriol in fetal blood and the relation of estriol levels at birth to the development of respiratory distress syndrome. Pediatr Res 21:386-390

13. Kero PO, Pulkkinen MO 1979 Plasma progesterone in the respiratory distress syndrome. Eur J Pediatr 132:7-10

14. Jiang C, Finkbeiner WE, Widdicombe JH, McCray PB, Miller SS 1993 Altered fluid transport across airway epithelium in cystic fibrosis. Science 262:424-427

15. Corey M, Farewell V 1996 Determinants of mortality from cystic fibrosis in Canada 1970-1989. Am J Epidemiol 143:1007-1017

16. Shanklin DR, Wolfson SL 1970 Aqueous estrogens in the management of respiratory distress syndrome. J Reprod Med 5:53-71

17. Trotter A, Ebsen M, Kiossis E, Meggle S, Kueppers E, Beyer C, Pohlandt F, Maie L, Thome UH 2006 Prenatal estrogen and progesterone deprivation impairs alveolar formation and fluid clearance of newborn piglets. Pediatr Res 60:60-64

18. Sweezey N, Tchepichev S, Gagnon S, Fertuck K, O'Brodovich H 1998 Female gender hormones regulate mRNA levels and function of the rat lung epithelial $\mathrm{Na}$ channel. Am J Physiol 274:C379-C386

19. Trotter A, Kipp M, Schrader RM, Beyer C 2009 Combined application of 17betaestradiol and progesterone enhance vascular endothelial growth factor and surfactant protein expression in cultured embryonic lung cells of mice. Int $\mathrm{J}$ Pediatr2009:170491

20. Jassal D, Han RN, Caniggia I, Post M, Tanswell AK 1991 Growth of distal fetal rat lung epithelial cells in a defined serum-free medium. In Vitro Cell Dev Biol 27A:625-632

21. Thome U, Chen L, Factor P, Dumasius V, Freeman B, Sznajder JI, Matalon S 2001 $\mathrm{Na}, \mathrm{K}$-ATPase gene transfer mitigates oxidant-induced decrease of active sodium transport in rat fetal ATII cells. Am J Respir Cell Mol Biol 24:245-252

22. Qin F 2004 Restoration of single-channel currents using the segmental k-means method based on hidden Markov modeling. Biophys J 86:1488-1501

23. Pasqualini JR, Kincl FA 1985 Hormone production and concentrations during pregnancy in humans and other mammalian species. In: Pasqualini JR, Kincl FA (eds) Hormones and the Fetus. Pergamon Press, Oxford, pp 173-334

24. Gambling L, Dunford S, Wilson CA, McArdle HJ, Baines DL 2004 Estrogen and progesterone regulate alpha, beta, and gammaENaC subunit mRNA levels in female rat kidney. Kidney Int 65:1774-1781

25. O’Brodovich H, Staub O, Rossier BC, Geering K, Kraehenbuhl JP 1993 Ontogeny of alpha 1- and beta 1-isoforms of $\mathrm{Na}(+)-\mathrm{K}(+)$-ATPase in fetal distal rat lung epithelium. Am J Physiol 264:C1137-C1143

26. Chow DC, Forte JG 1995 Functional significance of the beta-subunit for het erodimeric P-type ATPases. J Exp Biol 198:1-17

27. Thakur MK, Sharma PK 2007 Transcription of estrogen receptor alpha and beta in mouse cerebral cortex: effect of age, sex, 17beta-estradiol and testosterone. Neurochem Int 50:314-321

28. Gao L, Yankaskas JR, Fuller CM, Sorscher EJ, Matalon S, Forman HJ, Venglarik CJ 2001 Chlorzoxazone or 1-EBIO increases $\mathrm{Na}(+)$ absorption across cystic fibrosis airway epithelial cells. Am J Physiol Lung Cell Mol Physiol 281:L1123-L1129

29. Leroy C, Dagenais A, Berthiaume Y, Brochiero E 2004 Molecular identity and function in transepithelial transport of KATP channels in alveolar epithelial cells. Am J Physiol Lung Cell Mol Physiol 286:L1027-L1037

30. Nagar D, Liu XT, Rosenfeld CR 2005 Estrogen regulates \{beta\}1-subunit expression in $\mathrm{Ca}(2+)$-activated $\mathrm{K}(+)$ channels in arteries from reproductive tissues. Am J Physiol Heart Circ Physiol 289:H1417-H1427

31. Beckett EA, McCloskey C, O' Kane N, Sanders KM, Koh SD 2006 Effects of female steroid hormones on A-type K+ currents in murine colon. J Physiol 573:453-468 